\title{
Indirect Examination of Exocrine Pancreatic Function In Vivo by Determination of Chymotrypsin Activity in Animal Intestine Using a Synthetic Substrate
}

\author{
Rudolf Kaštel ${ }^{1}$, Ivan Rosival ${ }^{2}$, Michal Bartík $^{2}$ and Ján Blahovec ${ }^{2}$ \\ 1 Department of Nutrition, Dietetics and Forage \\ 2 Department of Chemistry, Biochemistry and Biophysics \\ University of Veterinary Medicine, Košice, Slovak Republic
}

Summary: Using the substrate $\mathrm{N}$-acetyl- $L$-tyrosyl-p-aminobenzoic acid, we determined chymotrypsin activity in the small intestine of calf, pig, and poultry. Orally administered $\mathrm{N}$-acetyl- $L$-tyrosyl- $p$-aminobenzoic acid is enzymatically cleaved in vivo, and the released $p$-aminobenzoic acid is determined by HPLC. We found that the $p$-aminobenzoic acid concentration in plasma and urine was significantly influenced by the feeding of soya flour. After soybean flour feeding, the $p$-aminobenzoic acid concentration significantly increased in the plasma of calves and hens, in contrast to pigs, where the $p$-aminobenzoic acid concentration significantly decreased. This shows that the oral administration of $\mathrm{N}$-acetyl- $L$-tyrosyl- $p$-aminobenzoic acid with subsequent determination of $p$-aminobenzoic acid is suitable for the estimation of exocrine pancreatic function and for determination of changes in intestinal proteolytic activity caused by antinutritive substances.

\section{Introduction}

Exocrine pancreatic insufficiency results in digestion failure, and failure of the small intestine to utilise nourishment, as well as other unfavorable consequences. Human exocrine pancreatic insufficiency is common and well described, but it is also common among dogs and cats. In other animal species it has been less investigated, largely due to the lack of suitable diagnostic methods (1). Exocrine pancreatic insufficiency is usually caused by chronic or acute diseases of the pancreas (2). Digestion failure and nourishment utilization failure can also be caused by the presence of antinutritive substances, and enzyme inhibitors in animal forage, which act largely by causing changes of proteolytic activity in small intestine.

None of these malfunctions, including diseases of the pancreas, are recognisable from specific signs. Since physical examination of the pancreas cannot be used to diagnose these malfunctions, it is necessary to rely on biochemical tests. The biochemical tests usually performed for this purpose include:

(a) blood examination: the determination of pancreatic enzyme $^{1}$ ) activity (amylase, lipase, trypsin) and fat $a b-$ sorption;

\footnotetext{
1) Enzymes:

$\alpha$-Amylase, 1,4- $\alpha$-D-glucan glucosohydrolase, EC 3.2.1.1;

a-Chymotrypsin, EC 3.4.21.1;

Lipase, triacylglycerol acylhydrolase, EC 3.1.1.3;

Trypsin, EC 3.4.21.4.
}

(b) faecal examination: the determination of total proteolytic activity or chymotrypsin activity in faeces.

This work aims to:

(a) investigate whether an in vivo indirect method using $\mathrm{N}$-acetyl- $L$-tyrosyl- $p$-aminobenzoic acid can be used for the determination of chymotrypsin activity in calves, pigs and poultry; and

(b) provided this method is suitable, to determine the influence of inhibitors, present in crude soybean flour, on chymotrypsin activity in the small intestine of the above-mentioned animals.

The orally administered substrate, $\mathrm{N}$-acetyl- $L$-tyrosyl- $p$ aminobenzoic acid, proposed by Mališ et al. (3) for human exocrine pancreatic insufficiency evaluation, was used for the in vivo determination of enzyme activity. A similar procedure has been used in dog (4). In this earlier work $(3,4)$, the $p$-aminobenzoic acid produced by chymotrypsin activity was determined spectrophotometrically. In the present study, however, we used a HPLC method, which has been described elsewhere (5).

\section{Materials and Methods}

\section{Reagents}

$p$-Aminobenzoic acid and $m$-hydroxybenzoic acid (internal standard), both of analytical grade, were obtained from Loba Chemie (Vienna, Austria). The synthetic substrate $N$-acetyl- $L$-tyrosyl- $p$ aminobenzoic acid was obtained from Léčiva (Prague, Czech Republic). Other reagents of analytical grade were from Lachema (Brno, Czech Republic). 
Tab. 1 Rations before and during the experiment

\begin{tabular}{lll}
\hline & $\begin{array}{l}\text { Feeding } \\
\text { beforc } \\
\text { the experiment }\end{array}$ & $\begin{array}{l}\text { during } \\
\text { the experiment }\end{array}$ \\
\hline Hens & $\begin{array}{l}\text { commercial } \\
\text { mixture }\end{array}$ & $\begin{array}{l}\text { commercial mixture and raw } \\
\text { soybean flour }\end{array}$ \\
Calves & $\begin{array}{l}\text { commercial } \\
\text { milk mixture }\end{array}$ & $\begin{array}{l}\text { commercial milk mixture and } \\
\text { raw soybean flour }\end{array}$ \\
& $\begin{array}{l}\text { commercial } \\
\text { mixture }\end{array}$ & $\begin{array}{l}\text { com, raw soybean flour, } \\
\text { supplement of minerals (Cu, Fe, } \\
\text { Zn, Mn, I, Co), and biofactors } \\
\text { (vitamins } \mathrm{A}, \mathrm{E}, \mathrm{D}_{2}, \mathrm{~B}_{2}, \mathrm{~B}\end{array}$ \\
& & $\begin{array}{l}\text { niacin, and lysine) } \\
\text { nigs }\end{array}$ \\
\hline
\end{tabular}

\section{High performance liquid chromatography}

HPLC SP 8700, model 770, Spectra Physics (Santa Clara, CA, USA) was used to determine $p$-aminobenzoic acid in blood, urine, and faeces. Analysis was performed on a Separon-Six $C_{18}$ (150 $\times 3.2 \mathrm{~mm}$ ) reversed-phase column, with $5 \mu \mathrm{m}$ particles (Laboratory Equipment, Prague, Czech Republic). For isocratic elution, the mobile phase consisted of methanol and $0.02 \mathrm{~mol} / \mathrm{l}$ ammonium acetate $\left(20+80\right.$, by vol.), $\mathrm{pH} 4.0$, at a flow rate of $0.5 \mathrm{ml} \cdot \mathrm{min}^{-1}$ (pressure $13.5 \mathrm{MPa}$ ). The peaks were detected at $280 \mathrm{~nm}$.

\section{Sample preparation}

Blood plasma $(1 \mathrm{ml})$ was deproteinised by the addition of $0.5 \mathrm{ml}$ $100 \mathrm{~g} / \mathrm{l}$ trichloroacetic acid containing a known amount of internal standard, and centrifuged at $900 \mathrm{~g}$. The supernatant was then hydrolysed with $6 \mathrm{~mol} / 1 \mathrm{HCl}$ at $104^{\circ} \mathrm{C}$ for 24 hours. After cooling, $0.1 \mathrm{ml}$ of the hydrolysate was neutralised by adding $0.9 \mathrm{ml}$ of 0.2 $\mathrm{mol} / \mathrm{l} \mathrm{NaOH}$. Fifty microltres of the sample (containing internal standard, $25 \mathrm{mg} / \mathrm{l}$ ) were injected into the column.

The urine of calves and pigs was filtered and centrifuged at $900 \mathrm{~g}$. Filtered urine samples $(0.5 \mathrm{ml})$ were hydrolysed by adding $1.0 \mathrm{ml}$ of $4 \mathrm{~mol} / 1$ sodium hydroxide (containing $0.2715 \mathrm{mmol}$ internal standard) and heating at $120^{\circ} \mathrm{C}$ for 1 hour in a screw-caped tube. Alkaline hydrolysis of urine appeared to be more efficient, because of the high content of $p$-aminobenzoic acid metabolites. After cooling, $0.1 \mathrm{ml}$ of the hydrolysate was neutralised by adding $0.9 \mathrm{ml}$ of $0.5 \mathrm{mmol}$ acetic acid. Fifty microlitres of the sample were injected into the column $(25 \mathrm{mg} / \mathrm{l}$ internal standard).

Hen faeces $(\mathrm{lg})$, mixed with distilled water $(5 \mathrm{ml})$, were left for 2 hours at laboratory temperature, then centrifuged at $1500 \mathrm{~g}$ for $10 \mathrm{~min}$. To $0.1 \mathrm{ml}$ of the supernatant (extract of faeces in distilled water) $0.1 \mathrm{ml}$ of a solution of $m$-hydroxybenzoic acid was added as the internal standard, followed by $0.8 \mathrm{ml}$ distilled water. The final concentration of the internal standard was $25 \mathrm{mg} / \mathrm{l}$. Fifty microlitres of the sample were injected into the column without hydrolysis. Total $p$-aminobenzoic acid concentrations were determined in blood, urine and faeces by HPLC chromatography (5).

\section{Animals and feeding}

Eight clinically healthy 16-month-old hens of Shaver breed, weighing $1.5-2.0 \mathrm{~kg} ; 7$ clinically healthy 10 -day-old male calves, weighing $35-44 \mathrm{~kg} ; 6$ clinically healthy $3-5$-month-old Landrace $\times$ Slovak white breed pigs, weighing $35-40 \mathrm{~kg}$ were used in the experiment. Animals were kept singly in metabolic cages.

During the preparatory period calves were fed with the commercial milk mixture Laktavit B (Milk Plant, Košice). In experimental feeding (see tab. 1) we added $100 \mathrm{~g}$ of soybean flour (Agrocass, Košice) for 7 days per calf and day. The standard commercial mixture NV-RM (Agrocass, Košice) was fed to hens in the preparatory feed. During the 7-day experiment, this mixture also contained fresh soybean flour ( $15 \mathrm{~g}$ per $75 \mathrm{~g}$ of feeding mixture), which increased the content of N-compounds in the diet from 157 to 183 $\mathrm{g} / \mathrm{kg}$. Hens received $120 \mathrm{~g}$ of mixture per day on average. Pigs were fed with the ČOS commercial mixture (Agrocass, Košice) in the preparatory period. During the 7-day experiment corn (1330 g), fresh soya $(570 \mathrm{~g})$, and supplements of biofactors and minerals were fed; see table 1 .

\section{Design of the experiment}

During the 14-day preparatory period, the animals were fed without the addition of soya flour (see tab. 2). After starvation for $24 \mathrm{~h}, \mathrm{~N}$-acetyl- $L$-tyrosyl- $p$-aminobenzoic acid was given orally by the use of a sond. The substrate was solubilized in an appropriate amount of physiological salt solution and always administered in the quantity of $250 \mathrm{mg} \mathrm{N}$-acetyl-L-tyrosyl-paminobenzoic acid per $\mathrm{kg}$ of body weight. Three hours after administration of the substrate, a blood sample was taken. Faeces and urine were collected in metabolic cages for 24 hours for the determination of $p$-aminobenzoic acid. This was then followed by a seven-day experimental feeding period, during which crude soya flour (containing protease inhibitors) was added to the animal forage. After this period, the same quantity of $\mathrm{N}$ acetyl- $L$-tyrosyl- $p$-aminobenzoic acid was given orally to the animals after a 24-hour period of starvation. The $p$-aminobenzoic acid concentration was determined in blood, faeces and urine at the same time intervals as described above.

\section{Statistics}

The results are shown as mean \pm standard error. Statistics were calculated by Student's t-test; values less than 0.05 were taken as significant. Coefficients of variation (CV) of the method were $1.1 \%$ for blood samples and $1.9 \%$ for urine samples.

\section{Results and Discussion}

The concentration of $p$-aminobenzoic acid, produced by chymotryptic cleavage of fed $\mathrm{N}$-acetyl- $L$-tyrosyl- $p$-aminobenzoic acid, was determined in the blood plasma and urine of calves and pigs, and in the blood plasma and faeces of hens. The results are given as a mean $\pm \mathrm{SE}$ of $p$-aminobenzoic acid (in $\mu \mathrm{mol} / \mathrm{l}$ ). The quantity of $p$ aminobenzoic acid was determined before and after the

Tab. 2 Study design

\begin{tabular}{|c|c|c|c|c|c|}
\hline $\begin{array}{l}\text { Commercial } \\
\text { feeding } \\
\text { before the } \\
\text { experiment }\end{array}$ & Starvation & $\begin{array}{l}N \text {-Acetyl- } L \text {-tyrosyl-p- } \\
\text { aminobenzoic acid } \\
\text { administration and sampling: } \\
\text { blood sample ( } 3 \mathrm{~h} \text { after } \\
\mathrm{N} \text {-acetyl- } L \text {-tyrosyl-p-amino- } \\
\text { benzoic acid administration), } \\
\text { collecting of urine, faeces }\end{array}$ & $\begin{array}{l}\text { Feeding } \\
\text { during the } \\
\text { experiment } \\
\end{array}$ & Starvation & $\begin{array}{l}N \text {-Acetyl- } L \text {-tyrosyl-p- } \\
\text { aminobenzoic acid } \\
\text { administration and sampling: } \\
\text { blood sample ( } 3 \mathrm{~h} \text { after } \\
\mathrm{N} \text {-acetyl- } L \text {-tyrosyl-p-amino- } \\
\text { benzoic acid administration), } \\
\text { collecting of urine, faeces }\end{array}$ \\
\hline (14 days) & (1 day) & & (7 days) & (1 day) & $\therefore$ \\
\hline
\end{tabular}




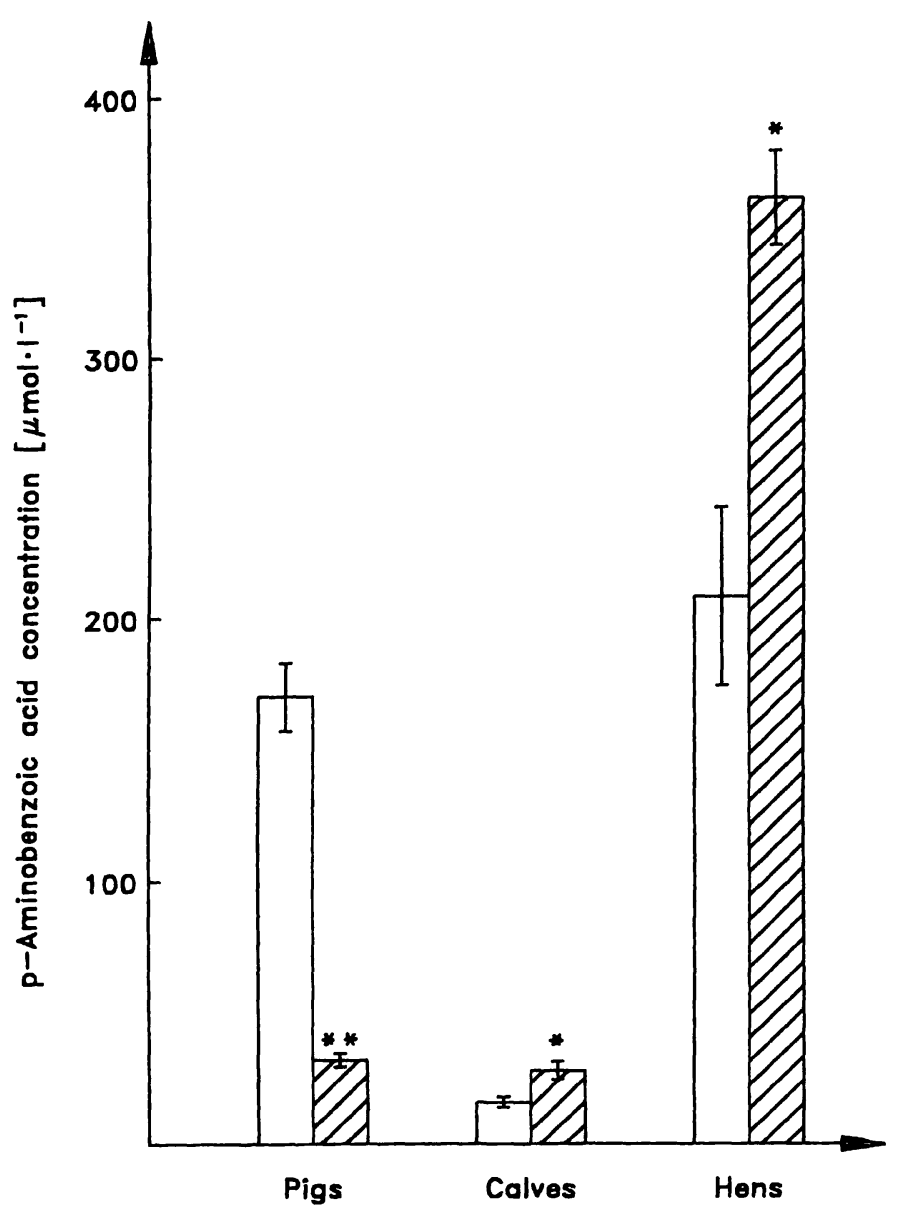

Fig. 1 Concentration of $p$-aminobenzoic acid in $\mu \mathrm{mol} / \mathrm{l}$ (mean \pm standard error) in pig $(n=6)$, calf $(n=7)$ and hen $(n=6)$ plasma. $\square$ - before supplementary feeding of raw soya.

- after supplementairy feeding of raw soya.

p-Aminobenzoic acid was evaluated by HPLC 3 hours after administration of $250 \mathrm{mg} \mathrm{N}$-acetyl- $L$-tyrosyl-p-aminobenzoic acid per $\mathrm{kg}$ of body weight.

${ }^{*} \mathrm{p}<0.05,{ }^{* *} \mathrm{p}<0.01$

addition of crude soya flour, containing protease inhibitors, to the forage. In all the animal species studied, the average $p$-aminobenzoic acid concentration in the blood plasma was significantly different before and after feeding soya flour (fig. 1).

In calf plasma, the $p$-aminobenzoic acid concentration increased after soya flour feeding from $16 \mu \mathrm{mol} / 1$ before administration to $27 \mu \mathrm{mol} / \mathrm{l}$ after $(\mathrm{p}<0.05, \mathrm{n}=7)$. As shown in table 3 , calf urine contains more $p$-aminobenzoic acid during the $24 \mathrm{~h}$ after feeding soybean flour than before the feeding. Expressed in fractions, approximately $19 \%$ of the $p$-aminobenzoic acid was eliminated in calves' urine within the $24 \mathrm{~h}$ before supplementary soybean feeding, whereas $26 \%$ was eliminated during the $24 \mathrm{~h}$ after the soybean supplement.

In hen plasma, the concentration of $p$-aminobenzoic acid increased after soya flour feeding from $203 \mu \mathrm{mol} / 1$ to $349 \mu \mathrm{mol} / 1(\mathrm{p}<0.05, \mathrm{n}=6)$. Approximately $11 \%$ of $p$ aminobenzoic acid was eliminated in hens' faeces within the 24 hours before supplementary soybean feeding, whereas $26 \%$ of the total amount administered was eliminated after soybean feeding.

The average concentration of plasma $p$-aminobenzoic acid before the experiment was $174 \mu \mathrm{mol} / 1$ in pigs. In contrast to calves and hens, the 7-day feeding of soya flour extract to pigs significantly decreased the concentration of $p$-aminobenzoic acid in the plasma to $33 \mu \mathrm{mol} / 1(\mathrm{p}<0.01, \mathrm{n}=6)$. Pigs fed supplementary soybeans flour excreted less $p$-aminobenzoic acid $(42 \%)$ than animals not fed the supplement $(63 \%)$.

The results in poultry and pigs are in accordance with data obtained by several authors. It was found that feeding protease inhibitors to pullets and hens causes an enlargement of the pancreas $(6-11)$ and an increase in intestinal proteolytic activity $(6,7)$. The presence of soya inhibitors in chicken-feed increases the release of the tissue hormone pancreozymin/cholecystokinin from the intestinal wall into the circulation (12) following pancreas stimulation. Yen et al. (13) affirm that pancreas enlargement was not found in slaughtered soybean-fed pigs, although trypsin and chymotrypsin activities were inhibited. The weight of pig pancreas is not increased during feeding with crude soybean fodder or with soya trypsin inhibitors $(8,11,14,15)$. After crude soya feeding we found, using indirect in vivo measurements, an increase (in poultry) or a decrease (in pigs) of proteolytic activity. This is not a new observation. The contribution of our work is the demonstration that information

Tab. 3 Concentration of $p$-aminobenzoic acid (mean $\pm S E$ ) in blood, urine and faeces of animals before and after supplementary feeding of soya. ${ }^{*} p<0.05,{ }^{* *} p<0.01$

\begin{tabular}{|c|c|c|c|c|}
\hline \multirow{2}{*}{$\begin{array}{l}\text { Animal } \\
\text { Calves } \\
\mathrm{n}=7\end{array}$} & \multirow{2}{*}{$\begin{array}{l}\text { Material } \\
\begin{array}{l}\text { Plàsma } \\
\text { Urine }\end{array}\end{array}$} & $\begin{array}{l}\text { Before soya feeding } \\
\mu \mathrm{mol} / 1\end{array}$ & \multicolumn{2}{|c|}{$\begin{array}{l}\text { After soya feeding } \\
\mu \mathrm{mol} /\end{array}$} \\
\hline & & $\begin{aligned} 16 & \pm 1.3 \\
2077 & \pm 478\end{aligned}$ & $\begin{array}{l}27.5 \\
2820\end{array}$ & $\begin{array}{l} \pm \quad 3.3^{*} \\
\pm 438^{*}\end{array}$ \\
\hline $\begin{array}{l}\text { Pigs } \\
\mathrm{n}=6\end{array}$ & $\begin{array}{l}\text { Plasma } \\
\text { Urine }\end{array}$ & $\begin{array}{cl}174.8 & \pm 18.2 \\
10611 & \pm 698\end{array}$ & $\begin{array}{l}33.0 \\
7091\end{array}$ & $\begin{array}{l} \pm 3.1^{* *} \\
\pm 1124^{*}\end{array}$ \\
\hline $\begin{array}{l}\text { Hens } \\
n=6\end{array}$ & $\begin{array}{l}\text { Plasma } \\
\text { Faeces }^{\mathrm{a}} \text { ) }\end{array}$ & $\begin{aligned} 203.8 & \pm 31.6 \\
0.14 & \pm 0.04\end{aligned}$ & $\begin{array}{r}349.2 \\
0.335\end{array}$ & $\begin{array}{l}18.3^{*} \\
0.06 *\end{array}$ \\
\hline
\end{tabular}

a) $p$-aminobenzoic acid concentration in non-hydrolysed faeces in $\mu \mathrm{mol} / \mathrm{g}$ 
on chymotrypsin activity in the intestine and therefore the exocrine function of the pancreas can be obtained by a procedure which until now had not been used in pigs, calves or poultry. The advantage of this method is that it does not require the introduction of a fistula or the sacrifice of animals.

There is little information on the influence of inhibitors of proteolytic enzymes on the physiological and biochemical processes of digestion in vivo, and on the exocrine function of the pancreas and its morphological changes in calves. Experiments with calves have been concerned mainly with the possibility of using soya protein in calf nutrition $(16-18)$. In addition to presenting an alternative method for examining the pancreas, our results for calves also provide new information on the effects of protease inhibitors on exocrine pancreatic function. We found that calf and pig pancreas responded to the soya inhibitors in the diet in different ways. Calves, in contrast to pigs, responded to the increased concentration of soybean inhibitors with increased exo-

\section{References}

1. Batt RM. Investigation of chronic diarrhoea in dogs. In: Leibeteder J, editor. Proceedings of the XVI. World Congress World Small Animal Veterinary Association (WSAVA); 1991 Oct 2-5; Vienna (A), Austria. 1991:170-1.

2. Batt RM. Canine exocrine pancreatic insufficiency - an overview. In: Leibeteder J, editor. Proceedings of the XVI. World Congress World Small Animal Veterinary Association (WSAVA); 1991 Oct 2-5; Vienna (A), Austria. 1991:153-5.

3. Mališ F, Frič $P$, Kasafirek E, Slaby J. Functional examination of the pancreatic secretion with 4-(N-acetyl-L-tyrosyl) aminobenzoic acid. Acta Hepato-Gastroenterol 1978; 25:233-7.

4. Freudiger V, Giegler B. Die Diagnose der chronischen exokrinen Pankreasinsuffizienz mit dem PABA-Test. Kleintier Praxis. $1977 ; 22: 45-84$.

5. Kaštel R, Rosival I, Blahovec J. Simultaneous determinations of $\mathrm{p}$-aminobenzoic acid and its metabolites in urine by highperformance liquid chromatography. Biomed Chromatogr 1994; 8:294-6.

6. Garlich JD, Neshiem MC. Relation of fractions of soybeans and crystalline soybean inhibitor to the effects of feeding unheated soybean meal to chicks. J Nutr 1966; 88:100-10.

7. Chernick SS, Lepkovsky S, Chaikoff IL. A dietary factor regulating the enzyme content of the pancreas: changes induced in size and proteolytic activity of the chick pancreas by the ingestion of raw soybean meal. Am J Physiol 1968; 155:33-41.

8. Birk Y. Protein protease inhibitors of plant origin and their significance in nutrition. In: Huisman J, Poel TFB, Liener IE, editors. Proceedings of the First International Workshop 1989 Dec 2-5; Wageningen, The Netherlands 1989:83-94.

9. Zhang Y, Parsons CM. Effect of soybeans varying in trypsin inhibitor content on performance of laying hens. Poultry Sci 1991; 70:2210-3.

10. Zhang $\mathrm{Y}$, parsons $\mathrm{CM}$, Weingartner $\mathrm{KE}$, Wijeratne WB. Effects of extrusion and expelling on the nutritional quality of conventional and Kunitz trypsin inhibitor-free soybeans. Poultry Sci 1993; 72:2299-308.

11. Guen MP, Birk Y. Protein protease inhibitors from legume seeds: nutritional effects, mode of action and structure-func- crine pancreatic activity. This appears to contradict the data of the above-mentioned authors which shows the same reaction to added protease inhibitors in pig, calf and dog. However, this difference can be accounted for by various factors. The effect of protease inhibitors depends on their form (raw, purified), on feeding, on the protein status of the animal and on the different amount and types of dietary proteins used in various experiments (11).

We believe that oral administration of the chymotrypsin substrate, $\mathrm{N}$-acetyl- $L$-tyrosyl- $p$-aminobenzoic acid, followed by $p$-aminobenzoic acid determination can be used in the diagnosis of pancreas diseases in animals. Moreover our results show that fluctuations of proteolytic activity in the small intestine, whatever their cause, can be detected by this method. Hence the method can also be used to determine protein digestion malfunctions and to investigate plant-protein-protease inhibitors and their influence on animals.

tion relationship. In: Poel AFB, Huisman J, Saini HS, editors. Proceedings of the Second International Workshop; 1993 Dec 1-3; Wageningen, The Netherlands. 1993:157-71.

12. Furuse M, Yang SI, Muramatsu T, Okumura J. Enhanced release of cholecystokinin by soya-bean trypsin inhibitor in chickens. Scand J Gastroenterol 1990; 25:1242-6.

13. Yen JT, Jensen AA, Simon J. Effect of dietary raw soybeans and soybeans trypsin inhibitor on trypsin and chymotrypsin activities in the pancreas and small intestinal juice of growing swine. J Nutr 1977; 107:156-65.

14. Schneeman BO, Gallaher D. Pancreatic response to dietary trypsin inhibitor: variations among species. In: Friedman $M$, editor. Nutritional and toxicological significance of enzyme inhibitors in foods. New York, London: Plenum Press, 1987:185-7.

15. Schulze H, Huismān J, Verstegen MWA, Leeuwen $P$ van, VanLeeuven P. Physiological effects of isolated soya trypsin inhibitors (sTI) on pigs. In: Poel AFB, Huisman J, Saini HS, editors. Proceedings of the Second International Workshop; 1993 Dec 1-3; Wageningen, The Netherlands. 1993:191-4.

16. Fiems LO, Bouque ChV, Cottyn BG, Buzsee FX. Cottonseed meal and maize gluten feed versus soybean meal as protein supplements in calf starters. Arch Animal Nutr 1986; 36:731-40.

17. Silva AG, Huber JP. Influence of substituting two types of soybean protein for milk protein on gain and utilization of milk replaces in calves. J Dairy Sci 1986; 69:172-80.

18. Tolman GH, Jansman AJM, Visser A, Beelen GM. Nutritional value of soya concentrates in veal calf diets differing in trypsin inhibitor activity. In: Poel AFB, Huisman J, Saini HS, editors. Proceedings of the Second International Workshop; 1993 Dec 1-3; Wageningen, The Netherlands. 1993:205-9.

\section{Received July 31/November 9, 1995}

Corresponding author: Rudolf Kaštel, Department of Nutrition, Dietetics and Forage, University of Veterinary Medicine, Komenského 73, SR-041 81 Košice, Slovak Republic 